\title{
Cervical Mucus Plug
}

National Cancer Institute

\section{Source}

National Cancer Institute. Cervical Mucus Plug. NCI Thesaurus. Code C92752.

A mucus plug situated in the maternal cervical os during pregnancy that prevents entry of bacteria into the uterus. 